\title{
BATAS WILAYAH DESA PASCA BERLAKUNYA UNDANG - UNDANG NOMOR 6 TAHUN 2014 TENTANG DESA
}

\section{BORDERS VILLAGE POST ENTRY IN TO LAW NUMBER 6 OF 2014 ABOUT THE VILLAGE}

\author{
Hasoloan Nadeak, Alexander Y Dalla, Deden Nuryadin, dan Anung S. Hadi \\ Badan Penelitian dan Pengembangan (BPP) Kementrian Dalam Negeri \\ Jl. Kramat Raya No. 132 - Senen, Jakarta \\ No. Telp./Faks: +62 213140454 ; HP. +62 85281700111 \\ Email: hnadeaklit@g.mail.com \\ alexander_dalla89@yahoo.com \\ Dikirim: 2 Juni 2015 Direvisi: 12 Juli 2015 Disetujui: 20 Agustus 2015
}

\begin{abstract}
Abstrak
Tujuan penelitian ini adalah untuk mengetahui dan menganalisis: realitas penetapan dan penegasan batas wilayah desa menurut UU No 32 tahun 2014, masalah dan solusi yang diambil untuk mengatasi masalah, peran camat dalam hal penetapan dan penegasan batas desa sesuai dengan UU No 23 Tahun 2014 tentang Pemerintahan Daerah. Pendekatan yang digunakan dalam penelitian ini adalah metode deskriptif kualitatif. Penelitian ini penting mengingat UU No 32 Tahun 2014 tentang Pemerintah Daerah, beberapa pasal telah dicabut dan dinyatakan tidak berlaku lagi, tetapi pasal yang mengamanatkan tentang batas desa tetap berlaku. Sementara itu telah terbit 2 (dua) UU yang baru sebagai penganti dan merupakan turunan dari UU no. 32 tahun 2004 yaitu, UU No. 6 tahun 2014 tentang Desa dan UU 23 tahun 2014 tentang pemerintahan daerah. Meskipun pengaturan tentang penetapan dan penegasan batas wilayah desa diatur secara rinci dalam peraturan Menteri Dalam Negeri (Permendagri) No. 27 tahun 2006 tentang Penetapan dan Penegasan Batas Desa sebagai turunan dari UU no. 32 tahun 2004 tentang dan peraturan pemerintah No. 72 tentang Desa namun dalam realitanya terjadi hal yang kotroversial, karena penetapan dan penegasan batas desa diatur secara teknis melalui Permendagri No. 27 tahun 2006 tersebut, tidak satupun para stakeholder yaitu para Bupati paling tidak di 4 (empat) provinsi daerah sampel penelitian yang mengimplementasikan Permendagri dimaksud dalam penetapan dan penegasan desa di daerahnya masing-masing.
\end{abstract}

Kata Kunci; Penetapan dan Penegasan Batas Desa, Pemerintah Daerah, Stakeholder.

\begin{abstract}
The purpose of this study is to determine and analyze: the reality of the establishment and affirmation of village boundaries according to Law No. 32 of 2014; problems and solutions are taken to address the problem; and; the role of the district head in terms of determination and demarcation of village boundaries according to Law No. 23 Year 2014 on Regional Government. The approach used in this study is a qualitative-descriptive method. This study is important due to in the Law No. 32 of 2014 on Local Government, several articles have been removed and no longer valid, but the article that mandates village boundaries are still applied. Meanwhile, has been published two (2) new law as a substitute, and as a derivative of the Law No. 32 2004, that is, Law No. 6 of 2014 on The Village and the Law No. 23 of 2014 on Local Government. Although the arrangement of the establishment and affirmation of village boundaries is provided in detail in the regulation of the Minister of Home Affairs (Permendagri) No. 27 in 2006, but in reality occur controversial thing. This is because the determination and village demarcation technically regulated by the Permendagri No. 27 In 2006 that none Regent/Bupati of four selected samples implementing the Permendagri referred to in the establishment and affirmation of the village in their own regions.
\end{abstract}

Keywords: Determination and The Affirmation of Village Boundaries, Local Government, Stakeholders.

\section{PENDAHULUAN}

Eksistensi desa di Indonesia atau nama lain seperti nagari di Minangkabau, Marga di Palembang, Gampong di Aceh, Huta atau Huria di Tapanuli sudah ada sejak lama dan mempunyai sejarah yang panjang. Sejarah yang panjang tersebut secara kronologis dapat dijelaskan, antara lain sebagai berikut: pertama, pada masa pemerintah Hindia
Belanda, yang memberlakukan Ordonantie atau undang-undang tentang desa yang disingkat IGO, berlaku untuk Jawa, Madura, dan Bali. Sedangkan Undang-undang Desa untuk luar Jawa disingkat IGOB.Dalam realitasnya Pemerintah Hindia tidak benar-benar berusaha untuk meningkatkan pemerintah desa, melainkan membiarkan begitu saja sebagaimana adanya dengan segala kekurangan dan kelemahannya.Tindakan-tindakan yang dilakukan 
Pemerintah Hindia-Belanda hanya sebatas untuk kelancaran administrasi pemerintahan kolonial, misalnya pemungutsn pajak, pemeliharaan keamanan dan ketertiban atau semacamnya, (Maschab 2013).kedua, pada masa pemerintahan Jepang, pengaturan mengenai desa diatur dalam Osamu Seirei Nomor 7 yang ditetapkan pada tanggal 1 Maret 1944 melalui aturan ini ditegaskan, bahwa kepala desa diangkat dengan jalan pemilihan, desa diposisikan setingkat diatas kampung atau dusun sebagai institusi terbawah, (Nurcholish 2011). ketiga, pasca Indonesia merdeka, kedudukan desa dapat dilihat dalam berbagai pengaturan yaitu:

a) Kedudukan desa berdasarkan UUD 1945, dibawah Undang-undang Nomor 22 Tahun 1948 tentang pemerintahan daerah

b) Kedudukan desa berdasarkan UUDS Tahun 1958 dibawah Undang-undang Nomor 1 tahun 1957 tentang pokok-pokok pemerintahan daerah

c) Kedudukan desa berdasarkan UUD 1945 masa orde baru dibawah Undang-undang nomor 5 tahun 1979 tentang pemerintahan desa.

Pada masa pemerintahan orde baru melalui Undang-undang nomor 5 tahun 1979, tidak mengatur desa sebagai kesatuan masyarakat hukum adat, melainkan mengatur kesatuan masyarakat yang didalamnya terdapat kesatuan masyarakat hukum. Jadi, yang diatur oleh Undang-undang nomor 5 tahun 1979 adalah sejumlah penduduk yang tinggal dalam suatu wilayah yang bernama desa.

d) Kedudukan desa berdasarkan UUD 1945 pasca amandemen dibawah Undang-undang nomor 22 tahun 1999 tentang pemerintahan daerah dan Undang-undang nomor 32 tahun 2004 tentang pemerintahan daerah. Kedua Undang-undang ini mengakui desa sebagai kesatuan masyarakat hukum adat, dengan hak-hak asal-usul dengan adat istiadatnya.

Oleh karena begitu tingginya dinamika sosial kemasyarakatan di Indonesia, yang berdampak tehadap penyelenggaraan pemerintahan, maka secara politis peraturan perundang-undangan perlu diperbaiki. Dalam rangka itulah Undang-undang Nomor 32 tahun 2004 tentang Pemerintahan Daerah diperbaharui dan diganti dengan dua undang-undang yang baru yaitu undang-undang Nomor 6 Tahun 2014 tentang Desa dan undang-undang Nomor 23 Tahun 2014 tentang Pemerintahan Daerah.

Kalau dilihat secara cermat UU 32 tahun 2004 tentang Pemerintahan Daerah, beberapa pasal diantaranya telah dicabut dan dinyatakan tidak berlaku lagi, akan tetapi pasal 216 UU no. 32 tahun 2014 tersebut yang secara khusus mengamanatkan terbitnya Peraturan Pemerintah (PP) nomor 72 tahun 2005 tentang Desa beserta turunannya yaitu Permendagri nomor 27 tahun 2006 tentang Penetapan dan Penegasan Batas Desa, yang merupakan amanat dari undang-undang nomor 32 tahun 2004 masih tetap berlaku. Sedangkan 2 (dua) undang-undang yang baru sebagaimana disebutkan yakni undang-undang nomor 6 tahun 2014 dan undang-undang nomor 23 tahun 2014, tidak mengatur atau mengamanatkan secara eksplisit satu pasal pun tentang penetapan dan penegasan batas desa. Dalam realitasnya saat ini Undang-undang nomor 32 Tahun 2004 telah dicabut dan dinyatakan tidak berlaku lagi dan diganti dengan undang-undang nomor 23 Tahun 2014, dalam pasal 225 ayat (1) huruf $\mathrm{g}$ menyebutkan bahwa tugas camat salah satunya adalah "membina dan mengawasi penyelenggaraan kegiatan desa dan /atau kelurahan “. Apabila dikaitkan dengan undang-undang nomor 6 Tahun 2014 tentang desa, dalam pasal 8 mengatur "pembentukan desa baru, dimana batas wilayah desa dinyatakan dalam bentuk peta desa yang telah ditetapkan dalam peraturan bupati".

Sesuai dengan kronologis seperti diuraikan di atas nampak ada kesinambungan atau keberlanjutan pengaturan tentang penetapan dan penegasan batas desa ke masa yang akan datang yang merujuk pada undang-undang nomor 32 Tahun 2004. Namun realitasnya peraturan mengenai penetapan dan penegasan batas desa ini belum dilaksanakan, maka potensi permasalahan batas desa akan banyak muncul kepermukaan. Sebagai contoh batas desa harus jelas, dikaitkan dengan rencana Pengucuran Alokasi Dana Desa (ADD) sebagimana terdapat dalam pasal 72 ayat 2 dan penjelasannya.

Dalam kaitan keberlanjutan kebijakan tentang penetapan dan penegasan batas desa ini, ada tiga (3) hal penting yang perlu diketahui dalam kaitan permasalahannya, yaitu:

a. Identifikasi Permasalahan:

(1) Sejarah keberadaan desa di Indonesia sudah cukup panjang, yang dimulai pada masa pemerintahan Hindia Belanda, Jepang sampai pada masa awal kemerdekaan Indonesia, namun aturan Undang-undang mengenai penetapan batas desa belum jelas atau bersifat umum.

(2) Pada masa pemerintahan Orde Baru, ditetapkan UU No. 5 Tahun 1979 tentang Pemerintahan Desa, lebih dominan mengatur tentang penyeragaman penyelenggaraan pemerintahan desa.

(3) Pada masa reformasi dengan UU No. 32 Tahun 2004, tentang Pemerintahan Daerah, mengamanatkan pengaturan penetapan dan penegasan batas desa.

(4) Permasalahan muncul karena Permendagri 27 tahun 2006 sebagai amanat UU No. 32 Tahun 2004yang masih tetap berlaku belum dilaksanakan, meskipun rentang waktunya sudah delapan (8) tahun.

b. Pembatasan Permasalahan

Sesuai dengan identifikasi permasalahan di atas, maka permasalahan dalam penelitian ini dibatasi yakni bagaimana keberlanjutan pengaturan dalam bentuk peraturan pelaksanaan 
dari petunjuk teknis tentang penetapan dan penegasan batas suatu desa yang hingga saat ini belum dilaksanakan pada daerah sampel yang ditentukan?

c. Rumusan Permasalahan

Merujuk pada pembatasan masalah di atas, maka rumusan masalah terkait dengan keberlanjutan pengaturan tentang pelaksanaan penetapan dan penegasan batas suatu desa, dikemukakan dalam tiga rumusan masalah yaitu:

(1) Bagaimana realitas penetapan batas desa sesuai dengan UU No. 32 Tahun 2004 beserta susunannya?

(2) Apa solusi yang diambil dalam mengatasi masalah pelaksanaan penetapan batas desa?

(3) Bagaimana peran camat dalam hal pelaksanaan penetapan dan penegasan batas desa sesuai dengan UU No. 23 Tahun 2014?

\section{METODE}

Kajian tentang "Batas Wilayah Desa Pasca Berlakunya Undang-Undang No. 6 Tahun 2014 tentang Desa", adalah merupakan bagian penelitian kebijakan (Policy Research).Oleh karena itu, pendekatan yang digunakan adalah metode deskriptif kualitatif yaitu untuk menggambarkan sifat suatu keadaan, fenomena, yang sementara berjalan atau berlangsung pada saat penelitian dilakukan dan memeriksa sebab-sebab dari suatu keadaan fenomena tertentu tersebut, (Consuello 1993:71).

Melalui kajian ini hendak melihat sejauh mana suatu kebijakan diimplementasikan dan bagaimana keberlanjutannya dalam mengatur penetapan dan penegasan batas wilayah Desa, dengan terlebih dahulu data dan informasinya dikumpulkan melalui instrumen penelitian.

a. Populasi dan sampel lokasi kajian

Populasi lokasi kajian ini dimaksudkan adalah seluruh atau tiga puluh empat (34) provinsi yang ada di Indonesia.Namun, karena keterbatasan, maka lokasi kajian ini ditentukan berdasarkan purposive sampling. Artinya, sampel lokasi ditentukan berdasarkan ciri-ciri tertentu. Adapun ciri-ciri tertentu dimaksud adalah:

1) Provinsi yang mempunyai keistimewaan seperti Provinsi Yogyakarta.

2) Provinsi yang berbatasan langsung dengan ibukota negara DKI Jakarta dan merupakan Provinsi Pemekaran seperti Provinsi Banten.

3) Provinsi yang mempunyai keanekaragaman yang terdiri dari beberapa sub etnis, suku dan budaya, namun hidup bersama dan rukun, seperti Provinsi Sumatera Utara. Sebagai contoh, sub etnis Simalungun yang tinggal di Kabupaten Simalungun berbatasan dengan sub etnis Batak Karo yang tinggal di Kab. Karo. Namun dalam realitasnya Suku Batak Karo tinggal menetap di Kab. Simalungun, yang secara geografis hidup berbatasan.
4) Provinsi yang mempunyai jumlah penduduk terbanyak di Indonesia seperti Prov. Jawa Barat. Secara spesifik sebenarnya provinsi ini memiliki mobilitas penduduk baik antar desa, kecamatan bahkan antar kabupaten, karena transportasi yang lancar.

Berdasarkan penjelasan di atas, maka sampel lokasi pada tataran provinsi ada empat (4) Provinsi yaitu: (1) Provinsi Yogyakarta, (2) Provinsi Banten, (3) Provinsi Sumatera Utara, dan (4) Provinsi Jawa Barat.

b. Informan

Untuk mendapatkan data dan informasi yang menyangkut batas wilayah desa, sesuai judul penelitian, maka dibutuhkan informan yang secara formal ada di dalam perangkat daerah provinsi, kabupaten yang mempunyai tupoksi menyangkut/terkait dengan penyelenggaraan pemerintahan desa, kecamatan, bahkan sampai kepada desa/perangkat desa.Dengan demikian, informan dalam kajian ini terdiri dari:

1) Kepala Biro Tata Pemerintahan pada tingkat Provinsi atau nomenklatur lainnya.

2) Kepala Bagian Pemerintahan pada tingkat Kabupaten atau nomenklatur lainnya.

3) Camat.

4) Kepala Desa

5) Tokoh Masyarakat

Dengan demikian, informan dalam kajian ini seluruhnya 5 (lima) orang.

Data yang dibutuhkan dalam kajian ini terdiri dari dua jenis data, yaitu: data sekunder dan data primer. Untuk data sekunder seperti kebijakan yang ditetapkan dalam bentuk Peraturan Daerah Provinsi, Kabupaten, Peraturan Gubernur, Bupati, Keputusan Gubernur, Bupati, yang terkait dengan kebijakan batas wilayah desa, dapat diminta secara langsung kepada informan. Sedangkan data primer dapat diperoleh melalui instrument wawancara yang telah disiapkan.

Setelah data atau informasi berhasil dikumpulkan melalui wawancara, maka data atau informasi tersebut diolah sesuai dengan tahapan berikut:

1) Mengevaluasi jawaban informan yang terekam melalui catatan-caatatan lepas, kemudian dihimpun sehingga menjadi satu kesatuan, terstruktur dan sistematis.

2) Melihat signifikansi atau pentingnya informasi yang dicatat.

3) Mengklasifikasi atau mengkoding informasi yang mirip atau kecocokan informasi satu dan lainnya.

4) Menyusun jawaban informan dalam satu tabel sesuai dengan indikator atau topik yang ditanyakan (Rao 2010:123).

Setelah data dan informasi terkumpul dan tahapan telah dilakukan, maka dianalisis dengan cara penafsiran data dan informasi. Lebih jauh Rao 
(2010) menjelaskan analisis data deskriptif sebagai berikut:

"Penafsiran berarti pengembangan ide berdasarkan hasil temuan dan menghubungkannya dengan teori yang ada dan konsep-konsep yang telah ditetapkan sebelumnya secara mendalam.Penafsiran dilakukan sesudah tersedia, sudah lengkap dan jelas data atau informasi yang didapat, karena hanya dengan demikian penafsiran dapat dibuat. Penafsiran juga berarti mencari dan menemukan hal baru, unik atau significance pertanyaan-pertanyaan yang mendukung untuk menafsirkannya apakah yang baru atau unik dari hasil penelitian ini, apakah kontribusi hasil temuan ini untuk ilmu pengetahuan atau apa manfaat khusus dari hasil penelitian ini?

\section{HASIL DAN PEMBAHASAN}

Hasil dan pembahasan mengenai batas wilayah desa pasca berlakunya UU nomor 6 tahun 2014 tentang Desa, dapat dilihat dari 2 (dua) sisi yaitu sebagai berikut:

\section{Sebelum berlakunya UU nomor 6 tahun 2014 tentang Desa}

Semua provinsi pada lokasi kajian sebelum berlakunya UU nomor 6 tahun 2014 dan UU nomor 32 tahun 2004 beserta turunannya, desa dan batas desa sudah ada dan diakui secara turun temurun. Desa yang sudah ada dan batas desa yang sudah diakui secara turun temurun tersebut, disepakati secara alami seperti pemantang sawah, sungai besar atau kecil (parit), pohon pohonan. Pengakuan secara normatif pun sebenarnya sudah ada seperti dalam Tabel 1.
Penetapan dan Penegasn Batas Desa, Pemerintah Kabupaten/Kota tidak secara otomatis melaksanakan dan bahkan satupun dari daerah sampel belum mengimplementasikannya, padahal rentang waktunya sejak tahun 2006 sudah \pm 8 tahun dan bahkan UU No. 32 Tahun 2004 Tentang Pemerintahan Daerah yang merupkan payung hukum terbitnya Permendagri tersebut beberapa pasal sudah dicabut dan dinyatakan tidak berlaku lagi.

Sebenarnya, secara empirik bukan hanya Permendagri tentang Penetapan dan Penegasan Batas Desa yang kurang direspons oleh para Bupati/Walikota, tetapi Peraturan Pemerintah No. 19 Tahun 2008 tentang Kecamatan, juga kurang direspons oleh para Bupati/Walikota untuk menyerahkan sebagian kewenangan Bupati/Walikota kepada Camat/ Kecamatan, yang notabene PP No. 19 Tahun 2008 adalah amanat dari UU 32 tahun 2004..

$$
\text { Kurangnya respons Pemerintah }
$$

Kabupaten/Kota, terutama dalam kaitannya dengan Penetapan dan Penegasan Batas Desa ini, faktor penyebabnya diantaranya adalah: (1) kurang proaktifnya atau tidak menjadi prioritas Bupati/Walikota, (2) anggaran tidak tersedia dalam APBD, (3) mahalnya biaya penetapan dan penegasan batas desa dan kurangnya tenaga ahli, (Wawancara dengan salah seorang pejabat eselon IV pada Badan Pemmas dan Pemdes Prov. Sumatera Utara tanggal 11 November 2014).

Kalau ketiga faktor di atas disandingkan dengan Permendagri tentang Penetapan dan Penegasan Batas Desa, sulit dibantah bahwa permendagri yang mengatur penetapan dan penegasan batas desa sangat membebani APBD

Tabel 1. Realitas Dasar Hukum Penetapan Batas Desa Sesuai Daerah sampel Lokasi

\begin{tabular}{|c|c|c|c|}
\hline No & Provinsi & Kabupaten & Dasar Hukum \\
\hline & Sumatera Utara & Deli Serdang & $\begin{array}{l}\text { 1. UU Darurat No.7 Tahun } 1956 \text { Tentang } \\
\text { Pembentukan Daerah otonom pada } \\
\text { Kabupaten-kabupaten di Propinsi } \\
\text { Sumatera Utara. } \\
\text { 2. PP No.7 Tahun } 1984 \text { tentang } \\
\text { Pemindahan Ibukota Kab. Deli Serdang } \\
\text { dari Kota Medan ke Kota Lubuk Pakam } \\
\text { Kab. Deli Serdang }\end{array}$ \\
\hline 2. & Jawa Barat & Kabupaten Cianjur & $\begin{array}{l}\text { Peraturan Gubernur No. } 44 \text { Tahun } 2012 \\
\text { tentang Pedoman Penetapan dan penegasan } \\
\text { batas desa. }\end{array}$ \\
\hline 3. & Banten & Pandeglang & $\begin{array}{l}\text { UU No. } 23 \text { Tahun } 2000 \text { tentang } \\
\text { Pembentukan Provinsi Banten }\end{array}$ \\
\hline 4. & DI. Yogyakarta & Bantul & $\begin{array}{l}\text { UU No. } 3 \text { Tahun } 1950 \text { tentang } \\
\text { pembentukan daerah Istimewa Jogjakarta; }\end{array}$ \\
\hline
\end{tabular}

Sumber: Diolah dari data sekunder

Dengan demikian, realitas penetapan dan penegasan batas desa disemua provinsi kabupaten daerah sampel belum merujuk pada Permendagri 27 tahun 2006. Artinya, meskipun Permendagri No. 27 Tahun 2006 sebagai petunjuk teknis (juknis) dalam
Kabupaten. Hal ini terlihat dari tahapan-tahapan penetapan dan penegasan batas desa tersebut mengatur hal-hal berikut:

(1) Tujuan Penetapan dan Penegasan Batas Desa, yaitu untuk memberikan kepastian hukum 
terhadp batas desa di wilayah darat dan sebagai acuan dalam melaksanakan kegiatan penetapan dan penegasan batas desa secara tertib.

(2) Tata cara penetapan dan penegasan batas desa, meliputi:

a. melalui tahapan penelitian dokumen

b. penentuan peta desa yang dipakai

c. delinisiasi garis batas secara kartometrik di atas peta dasar.

(3) Penegasan Batas Desa melalui tahapan, yang meliputi:

a. tahapan penentuan dokumen penetapan batas

b. pelacakan garis batas

c. pemasangan pilar disepanjang garis batas

d. pengukuran dan penentuan posisi pilar batas

e. pembuatan peta garis batas dengan koridor tertentu.

Terhadap penegasan batas desa tersebut di atas dilakukan berdasarkan prinsip-prinsip geodesi dan setiap tahap dituangkan dalam berita acara kesepakatan antar desa yang berbatasan serta pembuatan peta garis batas dilakukan apabila kedua desa yang berbatasan menganggap perlu. Disamping tahapan-tahapan seperti dijelaskan, juga perlunya dibentuk terlebih dahulu Tim Penegasan dan
Umum; (6) Dinas Tata Ruang; (7) Dinas Tata Kota; (8) dan lain-lain.

Di samping sangat membebani APBD juga persoalan-persoalan mengenai perbatasan desa selama ini belum ada yang muncul ke permukaan sehingga Bupati/Walikota menganggap belum terlalu prioritas penanganan penetapan dan penegasan Bata Desa dimaksud. Padahal tujuan Penetapan dan Penegasan Batas Desa tersebut adalah untuk memberikan kepastian hukum.

Dalam Tabel 2 dikemukakan persoalanpersoalan yang muncul kepermukaan di semua lokasi sampel. Hal lain yang sangat pelik juga adalah batas Desa Durian Kecamatan Pantai Labu dengan salah satu Desa yaitu Desa Urip di Kecamatan Beringin Kabupaten Deli Serdang Provinsi Sumatera Utara yang hampir hilang karena tergerus. Lokasi kejadian ini sangat dekat dengan Bandara Kuala Namu.Seiring dengan itu, jual beli tanah sangat tinggi karena lokasinya yang sangat strategis berdekatan dengan Bandara Kuala Namu, tetapi ketidakpastian hukum sangat rentan terjadi.Dengan demikian, pelayanan publik kepada masyarakat dibidang pertanahan sangat tidak memberikan kepastian hukum, yang dapat berdampak terjadinya gejolak sosial di kemudian hari.

Tabel 2. Persoalan yang Muncul di Permukaan Menurut Lokasi Sampel Kajian

\begin{tabular}{|c|c|c|c|c|}
\hline No. & Kabupaten & Kecamatan & Desa & Permasalahan \\
\hline 1. & Deli Serdang & Batang Kuis & Sena & $\begin{array}{l}\text { 1. } \begin{array}{l}\text { Kepala Desa Tanjungsari } \\
\text { memberikan rekomendasi tentang } \\
\text { tanah yang bukan wilayahnya }\end{array} \\
\text { tetapi wilayah Desa Sena. } \\
\text { 2. Kepala Desa Tumpatanibung } \\
\text { memberikan rekomendasi tentang } \\
\text { tanah yang bukan wilayahnya } \\
\text { tetapi wilayah desa sena }\end{array}$ \\
\hline 2. & Pandeglang & Cimanuk & Kupahandap & $\begin{array}{l}\text { Ada warga yang memiliki sawah di } \\
\text { desa yang bukan merupakan tempat } \\
\text { domisilinya sehingga terkait dengan } \\
\text { APBDes tidak bisa dipungut } \\
\text { retribusinya. }\end{array}$ \\
\hline 3. & Cianjur & Cibeber & Cihaur & $\begin{array}{l}\text { Pengurangan luas desa cihaur atas } \\
\text { pergeseran batas yang disebabkan oleh } \\
\text { abrasi sungai yang dijadikan sebagai } \\
\text { batas desa }\end{array}$ \\
\hline 4. & Bantul & Kasihan & Bangunjiwo & $\begin{array}{l}\text { Permasalahan penggantian asset Desa } \\
\text { yang harus diganti oleh pemerintah } \\
\text { Kabupaten dengan mengambil wilayah } \\
\text { di desa lain dalam satu kecamatan. }\end{array}$ \\
\hline
\end{tabular}

Sumber: Diolah dari transkrip wawancara masing-masing lokasi kajian

Penatapan Batas Desa, yang ditetapkan dengan Keputusan Bupati/Walikota.Tim Penetapan dan Penegasan Batas Desa (P2BD) ini terdiri dari desadesa yang berbatasan. Unsur Instansi Teknis dimaksud terdiri dari: (1)Unit Tata Pemerintahan; (2) Bappeda; (3) Kantor Pertanahan; (4) Kantor Pajak Bumi dan Bangunan (PBB); (5) Dinas Pekerjaan
Juga hal lain, yang patut direspons oleh Pemerintah, ketika ditanyakan mengenai persepsi informan tentang penegasan dan penetapan Batas Desa ini, hasil wawancara dengan Camat Batang Kuis tanggal 11 Nopember 2014 bertempat di ruang kerja Camat, mengatakan:

"Penyelesaian batas desa ini ke depan saya ilustrasikan seperti mengupas bawang. Kalau kita 
mengupas bawang tidak perlu pakai keris bertuah, cukuplah dengan pisau dapur"

Artinya, penyelesaian batas desa itu tidak perlu serumit seperti yang diatur Permendagri dimaksud cukuplah yang sederhana, intinya adalah didasarkan pada kesepakatan kedua belah pihak, itu yang pertama dan utama.Kedua, batas-batas desa yang ada saat ini bukan baru ada setahun dua tahun, sudah ada sejak bertahun-tahun dari nenek-nenek moyang.Hanya saja batas-batas yang ada itu suatu ketika dapat rusak, hilang dan sebagainya, karena itu perlu ada patok-patoknya yang lebih permanen.

\section{Sesudah berlakunya UU nomor 6 tahun 2014}

Dalam realitasnya UU nomor 6 tahun 2014 tentang Desa, dalam pasal 8, mengatur tentang batas desa yang baru dibentuk yang dipetakan dalam peta desa dan ditetapkan dalam Peraturan Bupati. Ketentuan ini berlaku hanya bagi desa yang baru dibentuk, sedangkan batas desa yang sebelum undang-undang ini terbit sudah diatur dalam UU 32 tahun 2004 tentang Pemerintahan Daerah, dan beberapa pasal dalam Undang-Undang ini sudah dicabut serta dinyatakan tidak berlaku lagi.Sedangkan pasal yang berkaitan dengan pengaturan tentang batas desa masih tetap berlaku.Dengan demikian pertanyaannya adalah apakah penetapan dan penegasan batas desa yang diatur secara teknis dalam permendagri nomor 27 tahun 2006 masih tetap dipertahankan?Meskipun sampai saat ini bupati belum melaksanakannya padahal rentang waktu berlalu sudah 8 tahun. Berdasarkan hasil wawancara dengan Kepala Desa dan tokoh masyarakat di semua lokasi kajian, berharap agar ada petunjuk teknis penetapan dan penegasan batas desa ke masa yang akan datang dan juga harapan mereka agar petunjuk teknis tersebut menegaskan bahwa batas desa yang ditetapkan dan diakui secara turun-temurun hingga saat ini langsung ditetapkan dan ditegaskan batas desanya.

Jika dilihat pada Tabel 3 dikemukakan bahwa. tidak ada satu desa pun yang batas-batasnya sesuai dengan Permendagri No 27 Tahun 2006 tentang Penetapan dan Penegasan Batas Desa.

Merujuk pada informasi yang dikemukakan bahwa Batas Wilayah Desa dalam UU No. 6 Tahun 2014 adalah determinan atau faktor yang strategis mengingat kepastian hukum dalam hal, yakni:

a. Mewujudkan efektivitas dan akuntabilitas penyelenggaraan pemerintahan desa. Terkait dengan hal ini sebenarnya hendak mengatakan bahwa apabila telah terwujud batas suatu desa atau luasnya beserta jumlah penduduknya akan lebih mempermudah penyediaan pelayanan publik seperti penyediaan sarana prasarana jalan, sekolah, puskesmas atau rumah sakit. Namun yang terjadi selama ini, determinan strategis itu baru sebatas di atas kertas saja seperti data luas desa dalam tabel yang terdapat dalam data statistik. Belum ada kepastian hukum mengenai luas desa karena belum diikuti aturan sebagaimana dijelaskan di atas.

b. Menjamin kualitas tata kelola dan penyelenggaraan pemerintahan desa yang akuntabel. Dengan adanya kepastian hukum dalam penetapan dan penegasan batas desa seperti diutarakan yang merujuk pada Permendagri, maka akan dapat menjamin kualitas tata kelola dan penyelenggaraan pemerintahan desa, seperti antara lain semakin tertib pelayanan publik terutama dibidang pertanahan, penentuan pajak tanah dan bangunan semakin tertib, yang berdampak pada PAD Kabupaten/Kota yang bersangkutan. Meskipun tidak ada data dalam angka yang terdapat disajikan berapa penambahan PAD Kab.Deli Serdang dari PBB, namun pada tahun 2009 di Kecamatan Batang Kuis, Kantor Pajak Pratama Kab.Deli Serdang, sudah pernah mengukur lahan-lahan di desa yang ada di Kecamatan Batang Kuis.Namun, tidak ada informasi apakah Kantor Pajak Pratama Kab. Deli Serdang mengukurnya sesuai versi Permendagri No. 27 Tahun 2006 atau menggunakan versi atau aturan lain. Informasi dan data pengukuran lahan di desa-desa yang ada di Kecamatan Batang Kuis itu, tidak ada data pertinggalnya di Kantor Desa dan kantor Camat Batang Kuis, meskipun petugas dari kecamatan Batang Kuis sudah beberapa kali melakukan pendekatan ke Kantor Pajak Pratama Kab. Deli Serdang.

c. Menegaskan batas pengaturan wilayah-wilayah adalah desa.

Sesuai dengan hasil wawancara dengan salah seorang pejabat eselon pejabat IV pada Kantor Badan Pemberdayaan Masyarakat Desa dan Pemerintahan Desa (Badan Pemmas dan Pemdes) tanggal 11 Nopember 2014, yang menyatakan:

"masing-masing desa itu mempunyai sejarah masing-masing, ada yang desa adat ada yang desa dinas/pemerintahan (desa biasa). Secara umum di masing-masing Kab/Kota se Prov. Sumatera Utara, ada antara 2 atau 3 desa adat. UU No. 6 Tahun 2014 terbuka kemungkinan adanya pemerintahan desa adat, hal ini agar datur saja pelaksanaannya, karena hak dan kewajibannya sama dengan desa biasa. Untuk pembentukan desa adat ini perlu ada penegasan dari Pemerintah tentang pengertian atau pemahaman, apakah kebudayaan adat sama dengan desa adat, agar tidak ada kesalahan nanti di lapangan. Menurut saya, ada semacam ketidak konsistenan Pemerintah dalam menetapkan peraturan Perundang-undangan, seperti misalnya pada zaman Orde Baru ada UU No. 5 Tahun 1979 tentang Pemerintahan Desa, yang tidak mengakomodir desa adat. Dalam kaitan ini Pemerintah harus segera menerbitkan Peraturan 
Tabel 3. Realitas Penetapan \& Penegasan Batas Desa sesuai Permendagri No.27 Tahun 2006

\begin{tabular}{|c|c|c|c|c|c|}
\hline No & Provinsi & Kabupaten & Kecamatan & Desa & Keterangan \\
\hline 1. & $\begin{array}{l}\text { Sumatera } \\
\text { Utara }\end{array}$ & Deli Serdang & $\begin{array}{l}\text { Batang Kuis } \\
\text { Pantai Labu }\end{array}$ & $\begin{array}{l}\text { - Batang } \\
\text { Kuis Pekan } \\
\text { - Durian }\end{array}$ & $\begin{array}{c}\text { Belum merujuk } \\
\text { Permendagri } \\
\text { No.27/2006 }\end{array}$ \\
\hline 2. & Jawa Barat & Cianjur & Cibeber & $\begin{array}{l}\text { - Cihaur } \\
\text { - Cikondang }\end{array}$ & $\begin{array}{c}\text { Belum merujuk } \\
\text { Permendagri } \\
\text { No.27/2006 }\end{array}$ \\
\hline 3. & Banten & Pandeglang & Cimanuk & $\begin{array}{l}\text { - Kupahandap } \\
\text { - Batu Bantar }\end{array}$ & $\begin{array}{c}\text { Belum merujuk } \\
\text { Permendagri } \\
\text { No.27/2006 }\end{array}$ \\
\hline 4. & DI.Yogyakarta & Bantul & Kasihan & $\begin{array}{l}\text { - Bangunjiwo } \\
\text { - Tamantirto }\end{array}$ & $\begin{array}{c}\text { Belum merujuk } \\
\text { Permendagri } \\
\text { No.27/2006 }\end{array}$ \\
\hline
\end{tabular}

Sumber: Diolah dari data sekunder

Pelaksanaannya dan Petunjuk Teknisnya (juknis)".

Secara normatif dalam Pasal 96 s.d. Pasal 98 UU No. 6 Tahun 2014 mengatur tentang Penetapan Desa Adat. Dalam Pasal 96 UU ini mengatur: "Pemerintah, Pemerintah Daerah Provinsi dan Pemerintah Daerah Kabupaten/Kota melakukan penataan kesatuan masyarakat hukum adat dan ditetapkan menjadi Desa Adat"

Lebih jauh Pasal ini mengatur, bahwa Desa

Adat itu harus memenuhi syarat yaitu:

(1) kesatuan masyarakat hukum adat beserta hak tradisionalnya secara nyata masih hidup baik yang bersifat teritorial, genealogis, maupun yang bersifat fungsional.

(2) kesatuan masyarakat hukum adat beserta hak tradisionalnya dipandang sesuai dengan perkembangan masyarakat.

(3) kesatuan masyarakat hukum adat beserta hak tradisionalnya sesuai dengan prinsip NKRI

Tentunya syarat-syarat ini, harus diterjemahkan lebih detail lagi ke dalam petunjuk pelaksanaan atau pun petunjuk teknis.

d. Disyaratkan mutlak adanya bagi Desa dan Desa Adat untuk memiliki batas-batas wilayah yang jelas, karena secara teoritis dan konseptul, bahwa terselesaikannya penegasan batas desa (dan kelurahan) akan secara otomatis menyelesaikan batas-batas wilayah daerah otonom, karena desa dan kelurahan merupakan unit administasi terkecil dalam sistem pemerintahan di Indonesia.
Namun, dalam realitasnya, pertama, pada periode UU No. 32 Tahun 2014 dengan petunjuk teknisnya yang diatur dalam Permendagri No. 27 Tahun 2006 tentang Penetapan dan Penegasan Batas Desa, belum diimplementasikan oleh para bupati. Kedua, pada periode UU No. 6 Tahun 2014 ini, dalam Pasal 8 ditegaskan bahwa " Pembentukan Desa harus memenuhi syarat" diantaranya adalah "mempunyai batas wilayah desa yang dinyatakan dalam bentuk peta desa yang telah ditetapkan dalam Peraturan Bupati/Walikota".

Dengan demikian, terdapat dua masalah besar ke depan, yaitu: Pertama, bagaimana keberlangsungan penetapan dan penegasan batas desa berdasarkan UU No. 32 Tahun 2004 beserta aturan atau petunjuk teknis dalam Permendagri No. 27 Tahun 2006, karena pasal 216 UU 32 tahun 2004 masih tetap berlaku. Sementara itu sudah 8 tahun petunjuk teknis dimaksud belum diimplementasikan bupati.

Kedua, bagaimana penetapan dan penegasan batas desa saat berlakunya UU No. 6 Tahun 2014, dalam pasal 7 dan 8 hanya mengatur untuk batas desa yang baru atau pemekaran. Seiring dengan itu petunjuk teknis yang ada belum diimplementasikan para bupati meskipun sudah 8 tahun.

\section{Menghadapi Kondisi yang Kontroversial}

Saat ini sedang terjadi kondisi yang kontroversial, secara normatif ada aturan mengenai penetapan dan penegasan batas desa, namun dalam realitasnya tidak direspons para 
stakeholder/Bupati/Walikota untuk mengimplementasikannya, ada UU yang baru tetapi hanya mengatur batas desa untuk desa yang baru dibentuk yang nota bene harus merujuk pada petunjuk teknis yang diatur dalam UU 32 tahun 2004 beserta turunannya. Kondisi ini menimbulkan dampak tidak baik dalam hal tata kelola pemerintahan yaitu bupati tidak mentaati peraturan perundang-undangan tentang Penetapan dan Penegasan Batas Desa.Dalam kaitan ini, dampaknya Pemerintah, Pemerintah Daerah tidak memberi kapastian hukum apabila tidak segera diatasi.Dampak lainnya seolah-olah ada kekosongan peraturan perundang-undangan sebagai rujukan mengenai penetapan dan penegasan batas desa itu sendiri.Sesuai dengan data, ada sebanyak $77.000 \mathrm{desa} /$ kelurahan yang secara faktual penetapan dan penegasan batas wilayahnya belum jelas dan pasti.

Apabila dilihat fakta, perkembangan yang begitu cepat pada berbagai sektor pembangunan di desa, di satu sisi berimplikasi terhadap adanya peningkatan yang positif, namun, di sisi lain cenderung menimbulkan berbagai permasalahan. Masalah pembangunan tersebut, timbul sebagai akibat dari tekanan yang ditimbulkan oleh adanya peningkatan intensitas kegiatan yang terkait dengan ruang, sehingga menyebabkan ketidakseimbangan struktur dan fungsi ruang itu sendiri terutama di pedesaan dewasa ini, salah satunya adalah permasalahan batas wilayah desa (desa dan desa non adat).

Dengan demikian, disamping kondisi kontroversial yang dihadapi, juga dinamika perkembangan desa menurut UU No. 6 Tahun 2014 tentang Desa yaitu peluang adanya desa adat dan non adat, akan menambah kompleksnya persoalan yang dihadapi dalam pengaturan penetapan dan penegasan batas desa di Indonesia.

Atas dasar uraian di atas, secara prinsip dan teoritis berdasarkan karakteristik pembentukan-nya, maka persoalan batas wilayah desa perlu dicermati dengan seksama sesuai klasifikasi dan dasar, serta sifat dan jenis desa itu sendiri.UU No. 6 Tahun 2014 mengakui adanya perbedaan tersebut yang secara eksplisit diperkenalkan dengan sebutan desa dan desa adat.Desa non adat maksudnya adalah desa yang terbentuk atas dasar keputusan politik (elit lokal). Apa implikasi pembedaan desa adat dan desa non adat dalam persoalan batas wilayah? Ini adalah sesuatu yang menarik untuk dibahas dalam penelitian lebih lanjut.

Merujuk kepada teori "Primordialist of nationalism" dari Herder (1784), desa adat dapat diklasifikasikan kepada pengertian nasionalisme primordialist karena desa adat terbentuk atas dasar nilai-nilai hukum atau adat istiadat sebuah kelompok masyarakat yang bersifat primordial yang hidup di suatu wilayah. Karakteristik pendefinisian wilayahnya selalu merujuk kepada batas-batas fisik alamiah di lapangan, dan batas-batas tersebut dikenal dengan cara penunjukan oleh tetua adat. sedangkan batas desa non adat dapat ditentukan secara lebih bebas dan modern tidak bersifat primordial, merujuk kepada keputusan politik atau kepentingan administrasi pemerintahan. Pembedaan karakterisk antara desa adat dan desa non adat tersebut akan menentukan metoda penetapan dan penegasan batas nantinya. Untuk itu sebelum dilakukan penataan batas desa, perlu terlebih dahulu dilakukan inventarisasi dan pengklasifikasian desa adat desa non adat. Jadi pertanyaannya adalah: Berapa jumlah desa adat yang ada di Indonesia dan bagaimana cara menginventarisasinya?

Pertanyaan selanjutnya adalah: Bagaimana merumuskan model atau metoda dan pedoman penetapan dan penegasan batas wilayah desa untuk masing-masing karakterisik desa? Sehingga pada akhirnya dapat menjawab pertanyaan: Apakah Permendagri No. 27 Tahun 2006 masih relevan atau tidak, atau harus diganti? Bagaimana rumusan penggantinya?, ini persoalan lain yang harus dijawab.

\section{Kelembagaan}

Maju mundurnya, selesai tidak selesainya masalah penetapan dan penegasan batas wilayah desa sebenarnya sangat tergantung kelembagaan beserta sumberdaya manusia yang ada dalam lembaga dimaksud. Masalah kelembagaan dan sumberdaya manusianya sangat erat terkait dengan tugas pokok dan fungsi (tupoksi) lembaga itu sendiri dan juga masalah penganggaran adalah merupakan hal yang harus tersedia guna terwujudnya sasaran atau tujuan yang diharapkan sehingga disebut money follow function / uang mengikuti fungsi.

Terkait dengan penanganan penetapan dan penegasan batas desa, belum optimal meskipun secara kelembagaan sudah ada tupoksinya, pada Tabel 4 dikemukakan kelembagaan serta tupoksi yang menangani batas desa sebagai berikut. Berdasarkan tabel tersebut diketahui bahwa:

1. Pada tataran provinsi tidak menangani masalah batas desa tetapi menangani masalah batas kabupaten/kota.

2. Pada tataran kabupaten dengan nomenklatur yang berbeda tetapi secara tupoksi menangani masalah batas desa namun secara operasional belum melaksanakan tupoksi masalah batas desa dimaksud. Hal ini akan berdampak terhadap penyusunan program/kegiatan serta penganggarannya tidak berjalan semestinya, kasus ini terjadi di semua lokus kajian.

3. Penanganan batas kabupaten/kota di provinsi dan penanganan batas desa di daerah kabupaten, dilihat dari sisi pelaksanaan tugas dilapangan persoalan perbatasan ada di desa, oleh karena itu tupoksi penanganan perbatasan tersebut perlu ditinjau kembali baik dari sisi kelembagaannya maupun dari sisi tupoksinya agar tidak terjadi overlapping. 
Tabel 4. Kelembagaan dan Tupoksi yang Menangani Penetapan dan Penegasan Batas Desa pada Daerah Sampel

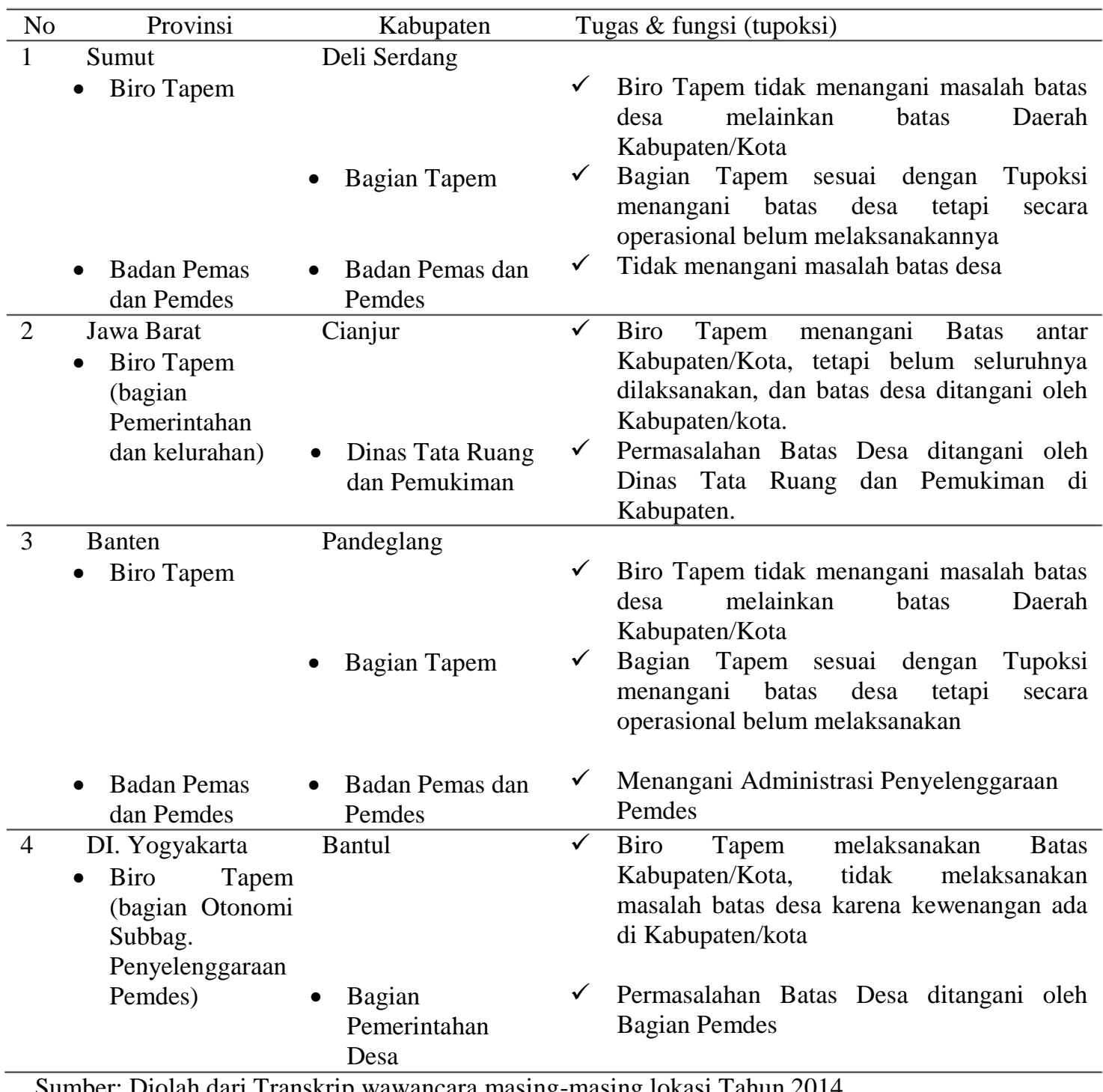

Kalau melihat penanganan batas desa seperti kondisi sekarang yang belum optimal oleh pemerintah kabupaten/kota, maka tujuan penetapan dan penegasan batas desa yaitu "memberikan kepastian hukum" menjadi tidak tercapai. Di samping itu banyak menyimpan potensi masalah di masing-masing Daerah, jika dibiarkan pada suatu saat akan muncul kepermukaan persoalan baru seperti "Mengalokasian Dana Desa (ADD)" sesuai dengan amanat Undang-Undang nomor 6 tahun 2014, karena luas wilayah desa menyangkut syarat untuk ADD dimaksud. Juga persoalan lain akan muncul, batas desa yang disepakati secara alami misalnya seperti batas desa yang pematang sawah, sungai, pohon, jalan yang suatu saat bisa saja hilang secara alami. Oleh karena itu Bupati/Walikota harus lebih proaktif untuk menggerakan unit kerja di jajarannya sesuai dengan tupoksi kelembagaannya, serta mengalokasikan/menyediakan anggaran dalam APBD.

\section{Peran Camat}

Peran yang dapat dilakukan oleh Camat dalam kaitan dengan penetapan dan penegasan batas desa ini dengan merujuk pada Pasal 225 UU No. 23/2014, maka secara umum peran Camat itu ada dua (dua), yaitu pertama, apabila ada sengketa perbatasan antar desa maka Camat berperan untuk mendamaikan kedua belah pihak dengan mencari win win solution (menguntungkan kedua belah pihak), kedua, apabila tidak ada masalah, semua pihak mau menerima apa yang sudah disepakati dan diputuskan bersama, maka Camat berperan sebagai pendamping atau mengesahkan apa yang sudah disepakati bersama. 
Di pihak lain, mengenai peran Camat ini ketika ditanyakan kepada para Kepala Desa dapat dilihat pada Tabel 5.
2. Apa solusi yang diambil oleh pemerintah kabupaten dalam mengatasi masalah penetapan dan penegasan batas desa?

Tabel 5. Usulan Informan Terkait Dengan Pemberian Kewenangan Kepada Camat dalam Penanganan Penetapan dan Penegasan Batas Desa

\begin{tabular}{|c|c|}
\hline Provinsi/Kabupaten & Jawaban Kades \\
\hline 1. Prov. Sumut/Kab. Deli Serdang & $\begin{array}{l}\text { Agar diberi porsi kewenangan camat, misalnya } \\
\text { melakukan identifikasi batas-batas desa yang ada } \\
\text { sekarang dalam hal melihat sejarah atau latar belakang } \\
\text { batas-batas desa tersebut, apakah ada dalam bentuk } \\
\text { perjanjian tertulis, bagaimana penerimaan semua pihak } \\
\text { terkait. }\end{array}$ \\
\hline 2. Prov. Kabar/Kab. Cianjur & $\begin{array}{l}\text { Agar camat diberi kewenangan untuk menelusuri dan } \\
\text { mengawasi batas-batas desa yang ada sekarang. } \\
\text { Agar Camat menata ulang batas-batas desa yang ada } \\
\text { sekarang. }\end{array}$ \\
\hline 3. Prov. Banten & $\begin{array}{l}\text { Camat diberi kewenangan untuk menelusuri dan } \\
\text { mengawasi batas-batas desa yang ada sekarang karena } \\
\text { sudah sejak lama batas-batas itu. } \\
\text { Melakukan inventarisasi terhadap patok-patok yang } \\
\text { bermasalah }\end{array}$ \\
\hline 4. Prov. D.I. Yogyakarta & $\begin{array}{l}\text { Camat diberi kewenangan untuk melakukan identifikasi } \\
\text { batas-batas desa yang ada sekarang. } \\
\text { Membuat daftar permasalahan atas patok-patok atau batas } \\
\text { desa yang bermasalah. }\end{array}$ \\
\hline
\end{tabular}

Sumber: Diolah dari hasil Wawancara Tahun 2014

Terkait dengan usulan, agar Camat diberi peran seperti dalam tabel di atas, hal ini perlu direspon dengan pertimbangan sebagai berikut:

a. Perlu dipertimbangkan kapasitas kecamatan baik dari sisi sumber daya manusia maupun tupoksinya;

b. Perlu ada kajian yang terkait dengan peraturan perundang-undangan yang ada.

Berdasarkan uraian dan penjelasan seperti diutarakan di atas, maka untuk menjawab rumusan permasalahan kajian ini, dikemukakan sebagai berikut:

1. Bagaimana realitas pelaksanaan petunjuk teknis yang diatur dalam permendagri no 27 tahun 2006 tentang penetapan dan penegasan batas desa, sesuai dengan amanat uu 32 tahun 2004 tentang Pemerintahan Daerah?

Terkait dengan pelaksanaan petunjuk teknis yang yang diatur dalam permendagri No.27 tahun 2006 tentang Penetapan dan Penegasan Batas Desa, dalam realitasnya belum dilaksanakan para bupati di empat (4) lokasi kajian. Hal ini disebabkan, karena batas desa yang sudah ada sudah lama ada, jauh sebelum Permendagri dimaksud ditetapkan, juga batas desa yang sudah lama ada ini, telah diakui dan diterima oleh masyarakat desa secara alami dan turun temurun seperti sungai, kali atau parit, pematang sawah, atau pohon-pohonan, dan belum ada batas desa yang permanen seperti terbuat dari beton.
Melihat realitas batas desa seperti dikemukakan, maka solusi yang diambil para Bupati relatif tidak ada dan bahkan lebih tepat dikatakan "terjadi pembiaran". Hal ini tidak boleh dibiarkan,perlu ada terobosan baru seperti peninjauan ulang atau memperbaiki juknis yang ada yaitu permendagri no.27 tahun 2006, karena berdasarkan temuan lapangan, Permendagri ini penerapannya membutuhkan biaya banyak sehingga biaya mahal (hight cost).

3. Camat perlu diberi kewenangan atau peran dalam kaitan penetapan dan penegasan batas desa, dengan pertimbangan dan kapasitas sumber daya manusia yang ada di kecamatan melalui suatu kajian mendalam.

\section{KESIMPULAN}

Merujuk pada data, informasi dan pembahasan yang dikemukakan, maka dapat disimpulkan bahwa "penetapan batas wilayah desa pasca berlakunya Undang-undang No.6 tahun 2014 tentang Desa", dapat dikemukakan sebagai berikut:

Sebelum berlakunya UU nomor 6 tahun 2014 tentang Desa. Semua provinsi pada lokasi kajian sebelum berlakunya UU nomor 6 tahun 2014 dan UU nomor 32 tahun 2004 beserta turunannya, desa dan batas desa sudah ada dan diakui secara turun temurun. Secara khusus batas desa yang sudah diakui dan diterima secara turun temurun tersebut, disepakati secara alami seperti pemantang sawah, 
sungai besar atau kecil (parit), pohon pohonan, dan sebagainya. Dengan demikan, penetapan dan penegasan batas wilayah desa pada provinsi sampel belum merujuk pada Permendagri No. 27 Tahun 2006 tentang Penetapan dan Penegasan Batas Desa, melalui tahapan yang harus diikuti yaitu: (1) pembentukan Tim Penegapan dan Penegasan Batas Desa; (2) tata cara penetapan dan penegasan batas desa; (3) penegasan batas desa melalui tahapan, yang meliputi: (a) tahapan penentuan dokumen penetapan batas; (b) pelacakan garis batas; (c) pemasangan pilar disepanjang garis pilar batas; (d) pengukuhan dan penentuan posisi pilar batas; (e) pembuatan peta garis batas dengan koridor tertentu; (f) dilaksanakan berdasarkan prinsip-prinsip geodesi.

Terhadap penegasan batas desa tersebut dilakukan berdasarkan prinsip-prinsip geodesi dan setiap tahap dituangkan dalam berita acara kesepakatan antar desa.

Sesudah berlakunya UU nomor 6 tahun

2014. Dalam realitasnya UU nomor 6 tahun 2014 tentang desa, dalam pasal 7 dan pasal 8, mengatur tentang penataan desa, syarat-syarat desa dan batas desa yang baru dibentuk yang dipetakan pada peta desa dan ditetapkan dalam Peraturan Bupati. Ketentuan ini berlaku hanya bagi desa yang baru dibentuk, sesuai dengan UU No. 6 Tahun 2004, sedangkan desa yang sudah ada sebelum uu ini masih tetap berlaku UU 32 tahun 2004 termasuk turunannya. Namun, bupati belum mengimplementasikan UU 32 tahun 2004 dalam penetapan dan penegasan batas desa dimasingmasing, meskipun rentang waktunya sudah delapan (8) tahun.

Saat ini sedang terjadi kondisi yang kontroversial, secara normatif ada aturan mengenai penetapan dan penegasan batas desa, namun dalam realitasnya tidak direspon oleh para stakeholder/Bupati/Walikota untuk mengimplementasikannya dalam menetapkan dan menegaskan batas desa di daerahnya.Ada UU yang baru tetapi hanya berlaku bagi pembentukan desa yang baru.Kondisi ini menimbulkan pertanyaan apakah pembentukan Desa yang baru tersebut harus merujuk pada Permendagri No.27 Tahun 2006 tentang penetapan dan Penegasan batas Desa.

Penetapan dan Penegasan Batas Desa dalam realitas penanganannya secara kelembagaan menimbulkan kerancuan tupoksi antara Biro Tata Pemerintahan dengan Badan Pemberdayaan Masyarakat Desa dan Pemerintahan Desa pada tataran Provinsi serta antara Badan Pemberdayaan Masyarakat Desa dan Bagian Pemerintahan Desa pada tataran Kabupaten.

Berdasarkan kesimpulan di atas, maka disarankan sebagai berikut.

Petunjuk teknis penetapan dan penegasan batas desa sebagaimana diatur dalam Permendagri no.27 Tahun 2006 harus ditinjau kembali, karena petunjuk teknis ini sangat sulit dilaksanakan dan membutuhkan biaya mahal sehingga membebani APBD. Dengan demikian, Bupati kurang merespon untuk melaksanakan di daerahnya.

Kemendagri perlu segera mendorong para Bupati/Walikota, agar secara proaktif membina dan menggerakkan unit kerja di lingkungannya untuk menegaskan siapa yang melaksanakan dan bertanggung jawab dalam tugas pokok dan fungsi dibidang Penetapan dan Penegasan Batas Wilayah Desa. Disamping itu perlu juga ditegaskan bahwa meskipun UU No.6 Tahun 2014 tentang Desa, namun terkait dengan penegasan batas desa tetap merujuk pada Permendagri No.27 Tahun 2006 tentang Penetapan dan Penegasan Batas Desa.

Pemerintah dalam hal ini Kementerian Dalam Negeri untuk segera menyusun dan membahas Peraturan Pelaksanaan dan Petunjuk Teknis tentang Penetapan dan Penegasn Batas Wilayah Desa yang lebih sederhana, bukan seperti yang ada sekarang yang sulit diterapkan dan mahal biayanya. 


\section{Daftar Pustaka}

Bayu, Surainingrat, (1980), Desa dan Kelurahan Menurut Undang-Undang Nomor 5 Tahun 1979 Jakarta, Tanpa Penerbit

Bintarto, R (1968), Buku Penuntun Geografi Sosial, Yogjakarta, UP. Spring.

Consello, Sevilla, G dkk (1993), Pengantar Metode Penelitian, Jakarta; Penerbit Universitas Indonesia (UI-Press), cet.pertama (Terjemahan).

Maschab, Mashuri (2013), Politik Pemerintahan Desa. Yogjakarta; PolGov, cet 1

Nurcholis, Hanif (2011), Pertumbuhan dan Peneyelenggaraan Desa. Jakarta: Penerbit Erlangga

Rao (2010), Metode Penelitian Kualitatif. Jakarta: Graha Ilmu, Edisi Pertama, cet Pertama

Suhartono, (1993), Bandit-Bandit Pedesaan di Jawa, Studi Historis, 1950 - 1942, Yojakarta; Aditya Media.
Sutisna,Sobar (2014), Berkenaan Dengan Penetapan dan Penegasan Batas Wilayah Desa Pasca Ditetapkannya UU No.06 Tahun 2014 Tentang Desa. (Makalah) Tidak dipublikasikan.

Wikipedia, Edisi Indonesia, Download tanggal 20 Oktober 2014

Undang- Undang Nomor 22 tahun 1994 tentang Pemerintahan Daerah

$$
\text { Nomor } 32 \text { tahun } 2004 \text { tentang }
$$

Pemerintahan Daerah

Nomor 6 tahun 2004 tentang Desa Nomor 23 tahun 2004 tentang Pemerintahan Daerah

Peraturan Pemerintah Nomor 72 Tahun 2005 tentang Desa

Peraturan Menteri Dalam Negeri Nomor 27 Tahun 2006 Tentang Penetapan dan Penegasan Batas Desa 